\title{
Pedagogical aspects of the formation of professional competence among students of physical culture and sports
}

\section{Aspectos pedagógicos da formação da competência profissional entre estudantes de cultura física e esportes}

\section{Aspectos pedagógicos de la formación de la competencia profesional entre estudiantes de cultura física y deportes}

\author{
Sergij Tkachov ${ }^{1}$ (D), Mykhailo Liannoi ${ }^{\text {iD }}$, Olha Shapovalova ${ }^{\text {iD }}$ \\ ${ }^{1}$ Kharkiv State Academy of Physical Culture, Kharkiv, Ukraine. \\ ${ }^{2}$ Sumy State Pedagogical University named after A. S. Makarenko, Sumy, Ukraine. \\ Corresponding author: \\ Sergij Tkachov \\ Email: lenok_leno@ukr.net

\begin{abstract}
How to cite: Tkachov, S., Liannoi, M., \& Shapovalova, O. (2021). Pedagogical aspects of the formation of professional competence among students of physical culture and sports. Revista Tempos e Espaços em Educação, 14(33), e16602.
\end{abstract} \\ http://dx.doi.org/10.20952/revtee.v14i33.16602
}

\begin{abstract}
The main purporse is to determine the main aspects of professional competence among students of physical culture and sports. The pedagogical practice of future physical culture teachers is an integrating and core component of the personal and professional formation of a future specialist, which provides for the formation of his professional competence through mastering various types of activity, leads to professional self-improvement, student self-knowledge in various professional roles in the real conditions of a general education school. Among the main tasks facing the system of higher pedagogical education, an important place is occupied by the task of training a competence-based specialist of a wide profile, further strengthening of fundamental education and bringing it closer to research and practical professional activity, therefore, the goal of training should provide for an optimal combination of theoretical knowledge and creative abilities of future teachers, which would allow them, after graduating from an educational institution, to independently raise the level of their education and professional training, to find fundamentally new solutions to the problems of science and practice. The study was carried out using the following theoretical methods: systems analysis and synthesis, induction and deduction, comparison, classification, generalization and systematization, idealization and abstraction. As a result of the study, the main aspects of professional competence among students of physical culture and sports were determined.
\end{abstract}

Keywords: Educational process. Pedagogy. Physical culture. Professional competence. Students. 


\section{RESUMO}

O objetivo principal é determinar os principais aspectos da competência profissional entre estudantes de cultura física e esportes. A prática pedagógica dos futuros professores de cultura física é um componente integrador e central da formação pessoal e profissional de um futuro especialista, que prevê a formação da sua competência profissional através do domínio de vários tipos de atividade, conduz ao autoaperfeiçoamento profissional, auto-aluno -conhecimento em vários papéis profissionais nas condições reais de uma escola de educação geral. Entre as principais atribuições do sistema de ensino superior pedagógico, um lugar importante é ocupado pela tarefa de formar um especialista por competências de amplo perfil, aprofundando o ensino fundamental e aproximando-o da investigação e da atividade profissional prática, portanto, o objetivo da formação deve proporcionar uma combinação ideal de conhecimentos teóricos e capacidades criativas dos futuros professores, o que lhes permitiria, após a formatura de uma instituição de ensino, aumentar de forma independente o seu nível de educação e formação profissional, para encontrar soluções fundamentalmente novas para os problemas da ciência e da prática. $O$ estudo foi realizado utilizando os seguintes métodos teóricos: análise e síntese de sistemas, indução e dedução, comparação, classificação, generalização e sistematização, idealização e abstração. Como resultado do estudo, foram determinados os principais aspectos da competência profissional entre estudantes de cultura física e esportes.

Palavras-chave: Alunos. Competência profissional. Cultura física. Pedagogia. Processo educacional.

\section{RESUMEN}

El objetivo principal es determinar los principales aspectos de la competencia profesional entre los estudiantes de cultura física y deportes. La práctica pedagógica de los futuros profesores de cultura física es un componente integrador y central de la formación personal y profesional de un futuro especialista, que prevé la formación de su competencia profesional a través del dominio de varios tipos de actividad, conduce a la superación profesional, la autoestima del alumno. -conocimiento en diversos roles profesionales en las condiciones reales de una escuela de educación general. Entre las principales tareas que enfrenta el sistema de educación superior pedagógica, un lugar importante lo ocupa la tarea de formar un especialista por competencias de amplio perfil, fortalecer aún más la educación fundamental y acercarla a la investigación y la actividad profesional práctica, por lo tanto, El objetivo de la formación debe proporcionar una combinación óptima de conocimientos teóricos y habilidades creativas de los futuros docentes, lo que les permitiría, después de graduarse de una institución educativa, elevar de forma independiente el nivel de su educación y formación profesional, para encontrar soluciones fundamentalmente nuevas para los problemas de la ciencia y la práctica. El estudio se llevó a cabo utilizando los siguientes métodos teóricos: análisis y síntesis de sistemas, inducción y deducción, comparación, clasificación, generalización y sistematización, idealización y abstracción. Como resultado del estudio se determinaron los principales aspectos de la competencia profesional entre los estudiantes de cultura física y deportes.

Palabras clave: Alumnos. Competencia professional. Cultura física. Pedagogía. Proceso educativo.

\section{INTRODUCTION}

The integration of the competence-based approach into the vocational training system is an objective necessity, which has formed in the educational space as a response to the socio-economic, political, educational and pedagogical challenges of the market economy in the context of globalization. The modern specialist is presented with requirements for which it is impossible to prepare him only because of the expansion of the subject content of professional training, because they are distinguished by a certain universality. Preparedness for professional activity, thus, is not limited to the systemic set of knowledge, skills and abilities - it requires certain socially and 
professionally significant qualities, formed motives and a conscious need for professional growth and self-development.

In American educational practice and research tradition, the category "competency" is often used, which determines the qualities, behavioral models that a person must possess in order to competently perform work. With this approach, the person performing the activity is analyzed and its activity is investigated. According to the British tradition, the category "competence" is more often used, which reflects the requirements for a specialist, which are highlighted by analyzing the functions of professional activity. Competency models are analyzed through professional standards containing a set of roles for each position. This allows the identification of individual competencies and behavioral indicators for each of them. In Western Europe, where a significant influence of the British model was felt, an integrated approach was subsequently formed that combined the behavioral, personal, cognitive and functional components of the specialist's model (AleksieienkoLemovska, 2019; Azimi et. al., 2020).

Professional competence is a basic and system-forming concept and is considered as a system of knowledge, skills and personal qualities that correspond to the content of professional activity, provides for: the person's awareness of his aspirations for activity - needs and interests; desires and value orientations; motive of activity, ideas about their social role; self-assessment of personal qualities and properties as a future specialist (professional knowledge, skills, skills, professionally important qualities; regulation of their professional development) and is defined as the readiness to carry out educational activities in accordance with specific conditions, requirements and tasks, as well as the ability to accompany the process self-knowledge, selfdevelopment of the student, to dynamize it in accordance with the specific essential inclinations of each child. The main chain that unites the entire system of professional training of a future physical culture teacher is pedagogical practice. Pedagogical practice of students is the leading, dominant means of preparing them for professional activity and one of the main means of forming the professional competence of future physical culture teachers.

In the modern world of environmental crises, environmental pollution, the problem of preserving the health of the population, in particular young people, is becoming increasingly important. The effective implementation of the health of preserved technologies in the educational process is largely associated with the professional pedagogical activity of teachers of educational institutions. Teachers of physical education of a professional college are the professional group that solves the most important tasks of introducing young people to a healthy lifestyle, organizing the health of the preserved environment in an institution, forming the readiness of future specialists for professional activities based on a value attitude towards the health of the population.

The exceptional importance of physical education actualizes the problem of developing the professional competence of physical education teachers, makes high demands on their active selfrealization and self-development. The system of methodological work of an educational institution is an important component of the educational process, since it is aimed at solving problems of improving the quality of professional activities of teachers on the basis of improving the content, forms and methods of teaching, the introduction of innovative technologies, modern educational and methodological support. That is why the methodological work of a professional college has significant potential for the development of the professional competence of teachers, including physical education, the direction of their professional activities to solve the problems of health preservation.

\section{METHODOLOGY}

The main purporse is to determine the main aspects of professional competence among students of physical culture and sports. For this, a number of methods were applied, which form the research methodology. The study was carried out using the following theoretical methods: 
systems analysis and synthesis, induction and deduction, comparison, classification, generalization and systematization, idealization and abstraction.

\section{RESULTS AND DISCUSSION}

Physical education of citizens is primarily associated with the personality of a physical education teacher, his professional knowledge, pedagogical skills and professional competence. After all, a physical education teacher should be one of the most competent specialists who conduct and coordinate actions according to the school's work plan for physical education, sports, recreation and tourism, organizing the work of students in physical education lessons and extracurricular activities, interacting with the teaching staff, parents in creating optimal conditions for physical education and a healthy lifestyle for students.

A competency-based approach to the professional training of a physical education teacher, based on interdisciplinary, integrated requirements for the result of educational activity, requires further scientific research, since it requires participants in the educational process to radically change both the goal and the vector of the content of higher physical education: from the transfer of knowledge and skills of subject content to the formation of a developed personality with life and professional competencies (Byrko et. al., 2021).

So, the orientation of the content of education towards the development of competencies, first of all, presupposes a thorough development of a system of competencies at various levels. Such a system should contain both elements of a complex of competencies related to content and structure and can develop among students gradually, depending on the subject, education, year of study, and competencies that go through the entire process of training a specialist and are not tied to only one subject. ... Only such an approach to the definition of learning outcomes at each of its stages will make it possible to carry out appropriate changes in the content of education, should be reflected in education standards and curricula in individual subjects. This idea of the essence and hierarchy of competencies creates a theoretical basis for the further development of the methodology and methodological tools for training a future specialist in physical education (Fullagar, 2019; Gonçalves Júnior et. al., 2021; Liannoi et. al., 2021; Melnykov, 2020; Nakhodkin et. al., 2021).

With regard to professional activity, research on the problems of vocational training in the context of education modernization uses the concept of "professional competence", the definition of which unites three groups - activities related to personality and related to knowledge, skills and abilities:

1) definitions related to activities - competence is disclosed as the degree to which the characteristics of a collective or individual subject correspond to the list of requirements for a particular profession:

- as the ability of a specialist to achieve a clearly defined goal, effective implementation of professional work in a specific area of activity. Competence is a personal characteristic that testifies to the real ability to perform professional actions;

- as the ability of an employee to perform their functions efficiently and accurately, both in normal and extreme conditions, to successfully master new knowledge and quickly adapt to changing conditions;

- as a series of issues in which the subject is endowed with knowledge, experience, and the totality of which reproduces the social and professional status and professional qualifications, as well as some personal, individual characteristics (abilities) and qualities that ensure the possibility of implementing a certain professional activity;

- as the ability of a specialist from the beginning of his professional activity at the level of a certain state-defined standard to meet the social requirements of the profession through effective professional activity and to demonstrate appropriate personal qualities, mobilizing for this the 
appropriate knowledge, skills, skills, emotions, based on his own internal motivation, attitude, moral and ethical values and experience, realizing the limitations in their knowledge and skills and accumulating other resources to compensate for them;

- as an evaluative category that characterizes a person as a subject of specialized activity, where the development of a person's abilities gives him the opportunity to perform qualified work, make decisions in problem situations, plan and improve actions that lead to the successful achievement of goals;

- as the level of a person's skills, it determines the degree of compliance with a certain competence, which allows one to act constructively in fast social conditions.

A teacher (teacher) of physical culture and vikhovannya is a pedagogical worker - a specialist in physical culture and sports, who has a higher or special pedagogical education and an appropriate educational and qualification level, organizes and carries out educational work with pupils (students) in order to form their physical culture, promoting the harmonious development of the personality, the formation of positive character traits, health promotion, improving physical and psychological preparation for an active life. The study of the professional competence of physical education teachers is inextricably linked with the study of professional and pedagogical activity, as a sphere of manifestation and application of the professional competence of a teacher - a specialist in physical culture and sports (Rusanivskyi, 2020; Tsybanyuk et. al., 2021).

Let's single out the following professional tasks of a physical education teacher:

- the formation of the concept that a person's care for his health, physical development is not only her personal affair, but also a public duty;

- promoting proper physical development and health promotion;

- correction of the physical development of lagging, weakened students with deviations from the normal state of health;

- development of the main types of motor actions, the formation of motor skills and abilities;

- the formation of students' correct posture, fit and neatness;

- the use of various forms of physical activity and other means of physical improvement;

- instilling skills and stimulating physical self-improvement and leading a healthy lifestyle;

- upbringing of sustainable interest and need for systematic physical education;

- ensuring the unity of extracurricular and classroom forms of physical education;

- promoting the interaction of the family and the institution in the process of physical education;

- assistance in organizing work on the formation of physical culture of students at the place of residence;

- organization of work with gifted youth who strive for sports excellence;

- involvement of the teaching staff, medical workers and public organizations in the process of forming physical culture;

- improving physical and psychological preparation for an active life and professional activity on the principles that provide a health-improving orientation and individuality of approaches;

- participation in the creation of an appropriate material base for organizing the process of forming students' physical culture.

Such a variety of professional tasks makes it necessary for teachers of physical education to master various types of professional activity. Among the types of professional activities of physical education teachers, domestic researchers have identified the following:

- diagnostic activity - is the implementation of a systematic analysis of capabilities both at the level of an individual and a social group. This makes it possible to predict their further development and consequences;

- rehabilitation activity - aimed at restoring the physical, mental, intellectual properties of a person; development of methodological support and implementation of rehabilitation programs; 
- reproductive activity - aimed at creating a socio-cultural environment necessary for the formation of a self-sufficient personality;

- sports activity - reveals the maximum capabilities of a person, his potential reserves, satisfies the needs for competitive activity;

- educational activities - aimed at teaching everyone to apply the acquired knowledge and skills in everyday life for self-improvement; ensures the rational formation of an individual fund of motor skills and abilities necessary in life; provides for educational and educational work, is implemented through the systematic transfer of the teacher and the subsequent assimilation by students of a certain amount of knowledge, their systematic replenishment and deepening.

Educational activity is aimed at assimilating the social and historical experience of mankind in the field of fundamental theory and education about the physical development of a person, and educational activity is to use special physical exercises to form a physically, mentally and socially mature personality;

- preventive activities or activities for the formation of a healthy lifestyle - aimed at ensuring the optimal development of physical qualities inherent in a person and on their basis - improving physical development; strengthening and maintaining health; improving the physique and the formation of posture; ensuring creative longevity;

- organizational activity - consists in drawing up the interaction of a person with other people in a group or in a society.

This also includes the preparation of technological operations in a certain area of physical development of an individual, group, society. The analysis of professional tasks and types of professional activity of physical culture teachers, taking into account its specificity, allows us to determine their professional functions:

- the teaching function is to transmit knowledge about physical culture as a component of the culture of society and the value of an individual, about health and a healthy lifestyle; the formation of skills and abilities of movement as a means of physical self-manifestation and selfimprovement, the formation of habits of daily physical activity in various types of activity;

- the developmental function provides for the creation of favorable conditions for the development of the child's physical potential, the formation of skills for physical self-development, self-realization and self-improvement, active recreation; an increase in the functional capabilities of his body through the development of basic physical qualities and natural abilities; a harmonious combination of physical development with aesthetic, moral, labor, mental, taking into account the individual psychological and age characteristics of students, their inclinations and abilities;

- the educational function is associated with the orientation of the professional activity of the teacher of physical culture to harmonize the goals that society sets for educational institutions with the needs of the individual in self-manifestation and self-realization; using the means of physical education in the formation of a system of physical, moral, aesthetic, civic and other qualities, values, attitudes and beliefs; education of patriotism, industriousness, responsibility, culture of mental work, active leisure, etc .;

- the health-improving function is associated with the formation of general ideas about the importance of physical culture in human life, the preservation and strengthening of health, the acquisition of elementary knowledge about the functioning of the human body, the work of its organ systems; instilling the priorities of a healthy lifestyle, health and hygiene skills and habits; development of physical activity, correct breathing, posture correction; accustoming to the use of means of physical culture for the prevention and removal of fatigue; accustoming and forming the skills of control and self-control over the state of health and well-being, the dynamics of indicators of physical development; creating conditions for health promotion and injury prevention and the like; 
- the gnostic function involves the knowledge of age characteristics and patterns of development of students, determination of the content and methods of pedagogical influence on them; analysis of the process and results of one's own activity, its disadvantages and advantages, determination on this basis of ways of correcting pedagogical influence; free and restoration of subject knowledge, methodological tools; continuous improvement of professional skills; planning and organizing one's own scientific, methodological and research work, and the like;

- the prognostic function consists in forecasting on the basis of diagnostics of the prospects for the development of the individual and the group, setting on this basis the goals and objectives of professional activity; determining, on a diagnostic basis, ways to optimize and correct the means of pedagogical influence, content, methods of pedagogical activity;

- the communicative function consists in organizing professional pedagogical communication, establishing relations and observing business and informal relations between teachers and students, all subjects of pedagogical influence; organizing effective interaction with colleagues, administration, parents, public and sports organizations, health services; observance of contacts with state and public physical culture and sports organizations, sponsors, and the like;

- the diagnostic function consists in a purposeful and specially organized study of the state and level of physical development of students, their individual characteristics, emotional-volitional states, abilities and inclinations; identifying the characteristics of the students in the group; determining on this basis the problems of general and physical development of the individual and their causes;

- the incentive function is to activate the educational, sports, motor activity of students; stimulating their independent, proactive work, maintaining and developing the interest of young people in physical culture and sports, physical improvement, health promotion, adherence to a healthy lifestyle; provides for the formation of the student's subjectivity in his own life, selfdevelopment and self-realization, and the like;

- the orientation function provides for helping students to comprehend and understand the ideals of physical development, self-improvement, health and a healthy lifestyle as components of universal human values; the formation of the value-orientational experience of these ideals and the personal value picture of the world;

- the constructive function is associated with the long-term and current planning of the educational process, one's own future activities and behavior in pedagogical interactions; selection of means, methods, techniques, forms of organization of training and educational, sports, educational, coaching work adequate to the individual characteristics of students, their state of health, capabilities and abilities; strengthening the material and sports base of the educational process and the like;

- the managerial function provides for the management during the lesson and during the extracurricular time the activities of students aimed at physical development and self-improvement, management of their self-development, teaching students to self-government by their own activities and the activities of the group in the course of classes, classes in sports sections, sports competitions, the work of a physical culture asset

- the corrective function involves the creation and maintenance of constant feedback in the "teachers-students" system, the analysis of one's own pedagogical activity, which makes it possible to correct the means of pedagogical influence, the content and organization of the teaching and upbringing process in accordance with its results;

- the organizational function is to attract students to various types of physical culture classes; organization and unification of the student body; material and technical support of the pedagogical process; expedient organization of professional activity, etc .; 
- the coordination function involves the coordination of the actions of all subjects of physical education in the educational institution and outside it to ensure optimal results and the development of the potential of students, etc.;

- the preventive function provides for the formation of knowledge, habits and skills of a healthy lifestyle, daily physical activity as a means of preventing diseases and physical disorders;

- the sports and recreational function consists in the formation of students, as well as the popularization among the parent and pedagogical community of various sports and active leisure;

- educational and popularization function is to disseminate and popularize among students, parent and teaching staff, the closest social environment of knowledge on physical culture, sports, daily physical activity, healthy lifestyle, as well as their importance for increasing efficiency, improving well-being, future professional activities; attracting student youth to popularize such knowledge in extracurricular work;

- the motor function is aimed at the development of the motor potential of students and presupposes the formation of their abilities to fulfill motor actions, creativity and improvisation in physical health-improving and sports activities; accustoming to physical improvement; expansion of motor experience, improvement of skills of vital motor actions and use in various types of activity (play, self-service, work, etc.);

- the methodological function involves the optimal selection of content, means, methods, accept, forms of organization of training and types of activities of students in the learning process in accordance with the goals and objectives of training and education, individual capabilities and needs of students in self-development; constant professional growth, renewal and improvement of professional competence and pedagogical skills.

Formation of professional competence of a teacher of physical culture, it is advisable to single out the following competencies in its structure: integral competences, containing a generalized description of the qualification level, expresses its main competence characteristics. On their basis, a description of the corresponding qualification level of the National Qualifications Framework is accepted; general competences - these are knowledge, understanding, skills and abilities that a student acquires in the framework of a certain training program, are universal; special competencies specific to the subject and directly related to the special knowledge in it, defining the profile of the program, that is, making it individual, significantly different from other programs (Zdanevych et. al., 2020; Zlatea \& Cucui, 2016).

The analysis of normative educational documentation makes it possible to determine the stages of improving theoretical and methodological work as an integral part of the development of professional competence of physical education teachers.

One of the main requirements for a professional in front of higher education today is one that covers the idea of what a modern person, a professional person should be, what is its purpose and role in society, the order for its education, expectations from education in a person, society. Education increasingly focuses on "free development", high culture, creative initiative, independence, mobility of future specialists, requires a qualitatively new approach to the formation of a future specialist. Methods for the development of professional competence of physical education teachers are focused on:

1) theoretical aspect - mastering the system of basic knowledge in the theory and practice of professional pedagogical activity in an educational institution;

2) practical aspect - the formation of a system of basic professional skills;

3) the personal aspect - the development and generalization of the basic subsystems of professional qualities, the development of a mature, positive professional self-concept, professional reflection, the activation of self-organization mechanisms, mental activity. Consequently, the process of development of the teacher's professional competence should provide for the activation 
of the processes of professional self-organization of the individual and their content (psychological and pedagogical) "content".

The competence-based approach allows implementing the main provisions of the professional training of a physical education teacher in the educational process:

- assimilation and implementation in professional training of labor and behavior standards, developed in the process of cultural and historical development of society;

- personal and professional development of a student, which is considered as the result of establishing a relationship between two lines of transition: "full-fledged activity - full-fledged intellect - full-fledged personality" and "full-fledged joint activity - full-fledged team - full-fledged personality";

- continuity in the formation of various levels of personality self-awareness (professional, spiritual and physical), which determine the formation of his worldview;

- the systemic organization of the educational process, provides for the fulfillment of two interrelated requirements: the planned formation of a holistic professional activity and a holistic personality, determines the logic of the development of means of pedagogical management of students' vital activity; the transition "from the general to the personal" in the assimilation of the educational content of each level and the selection for an individual student an appropriate list of educational and educational situations. The above allows to characterize the structural-functional model of the competence-oriented training of the future physical culture teacher, which, in our opinion, may consist of four interrelated blocks: managerial, substantive, procedural and effective.

It is advisable to consider the main tasks of the competence-oriented training of a physical education teacher:

1) the formation of professional knowledge among future specialists;

2) mastering by students the necessary complex of pedagogical skills and abilities;

3) assimilation by them of the experience of creative pedagogical activity in the field of physical culture and sports;

4) the formation of a system of value-emotional attitudes among students to pedagogical theory, the theory of physical culture, pedagogical activity and the process of preparation for it.

The solution of these tasks from the point of view of the competence-based approach provides for the formation of such knowledge and skills: - generalized theoretical knowledge about the nature, health and professional activity and the connections between them. The main functions of this knowledge are ideological preparation; - the ability to understand the organizational structure of professional activity and the integrated interdisciplinary specifics of physical culture, its relationship with the complex of disciplines of the social, humanitarian and professional blocks; the ability to assess standards, curricula and educational methods a view of the impact on the physical and spiritual aspects of the health of subjects of the educational process; - the ability to assess environmental, legal, industrial phenomena (studied or happen in life) from the point of view of the modern socio-cultural, physical culture and health-improving situation, and the like.

Modern directions, means and rational methods of physical education, created in the process of the creative activity of mankind, should be considered as innovative technologies of physical education. It is important to note that such technologies also include those borrowed for the purpose of creative use of the healing systems of different peoples of the world. Therefore, it is logical to conclude that for pedagogy as a science of upbringing, education and training, which for a long period of time was characterized by pedagogical innovation as an update of the educational system, the leading and determining criterion of its viability, compliance with social needs and needs, and competitiveness is innovation.

In our opinion, the key competencies of a physical education teacher are the ability for selfdevelopment and self-education, adaptability and mobility, creative activity, a researcher, integration of various pedagogical competencies, the ability to build a complex of individual values 
based on social and state priorities and to orient one's behavior and professional activity to them. Each of the key competencies is formed through training in a specific educational area, acquiring in this process the character of assimilation of educational components that are associated with educational tasks and the content of this industry.

A competency-based approach to the professional training of a physical education teacher, based on interdisciplinary, integrated requirements for the result of educational activity, requires further scientific research, since it requires participants in the educational process to radically change both the goal and the vector of the content of higher physical education: from the transfer of knowledge and skills of subject content to the formation of a developed personality with life and professional competencies.

\section{CONCLUSION}

The professional competence of a physical education teacher in the study is defined as a complex integrative state of his personality, which is characterized by a high level of theoretical, methodological, practical and psychological readiness to carry out professional and pedagogical activities, in accordance with qualification requirements. The high level of formation of the teacher's personal qualities and the ability to manifest a high level of social and pedagogical activity are also gaining in importance. This definition quite fully discloses the content of professional competence.

So, competence characterizes the ability of a person to successfully implement certain functions, carry out activities or solve problems, are external to the person and caused by social requirements and individual needs. Competence is formed and manifested in activity, and therefore represents a complex, multifaceted and multifaceted characteristic of this activity in accordance with the social order for it. How the potential of an individual is realized, it exists as a complex complex characteristic of it, a system of personal resources (knowledge, skills, methods of action, motives, relationships, personal qualities, value orientations, etc.) that provide effective action.

Authors' Contributions: Tkachov, S.: conception and design, acquisition of data, drafting the article, critical review of important intellectual content; Liannoi, M.: conception and design, acquisition of data, drafting the article, critical review of important intellectual content; Shapovalova, O.: conception and design, acquisition of data, drafting the article, critical review of important intellectual content. All authors have read and approved the final version of the manuscript.

Ethics Approval: Not applicable.

Acknowledgments: Not applicable.

\section{REFERENCES}

Aleksieienko-Lemovska, L. (2019). Components of professional competence of educators of pre-school educational institutions: pedagogical excellence, pedagogical creativity. Pedagogical sciences: reality and perspectives, 69, 5-9.

https://doi.org/10.31392/2311-5491/2019-69.1

Azimi, M., Rafsanjani, S. A. R. H., \& Torkaman, M. (2020). The effect of education and sporting experience of iranian premier league football players on their awareness of sports law. Revista Tempos e Espaços em Educação, 13(32), 115. https://doi.org/10.20952/revtee.v13i32.14924

Byrko, N., Tolchieva, H., Babiak, O., Zamsha, A., Fedorenko, O., \& Adamiuk, N. (2021). Training of teachers for the implementation of universal design in educational activities. Laplage in Journal, 7(Extra-D), 37-149.

https://doi.org/10.24115/S2446-622020217Extra-D1079

Fullagar, S. (2019). A physical cultural studies perspective on physical (in)activity and health inequalities: the biopolitics of body practices and embodied movement. Revista Tempos e Espaços em Educação, 12(28), 63-76. https://doi.org/10.20952/revtee.v12i28.10161 
Gonçalves Júnior, E. R., Siqueira, R. C. A., \& Gonçalves, E. R. (2021). Diffusion of environmental education in public education: evidence of a bibliometric analysis. Laplage in Journal, 7(1), 31-41. https://doi.org/10.24115/S2446$\underline{6220202171141}$

Liannoi, M., Dyshko, O., Melnyk, S., Chckailo, M., Hrybinichenko, A., Liakh, M., \& Illiashenko, A. (2021). Modern sports as an effective means of developing motor skills and the formation of applied skills in higher education. Laplage in Journal, 7(Extra-B), 568-574. https://doi.org/10.24115/S2446-622020217Extra-B972

Melnykov, A. (2020) Factors that influence change in cadets' physical preparation during the first half of study at the military academy. Journal of Physical Education and Sport, 18(2), 781-786

Nakhodkin, V., Khvatskaya, E., Ilina, N., Andreev, V., \& Andreev, V. (2021). Research on the state of young hockey players' pre-competitive psychological fitness. Laplage in Journal, 7(3), 283-291. https://doi.org/10.24115/S2446$\underline{62202021731296}$

Rusanivskyi, S. V., Fedchenko, O. S., Kruk, O. M., Oleksiychyk, S. A., Lysyk, R. V., Shtoma, V. D., \& Yuriev, S. O. (2020) Health status of instructional staff of highereducation institutions with special trainingconditions. Wiadomości Lekarskie, 74(1), 122-127

Tsybanyuk, O., Zavgorodnia, T. ., Hnes, N. ., Doronina, T. ., Strazhnikova, I. ., \& Dariichuk, S. . (2021). The role of public associations in the implementation of out-of-school education. Laplage in Journal, 7(3C), 613-618. https://doi.org/10.24115/S2446-6220202173C1668

Zdanevych, L. V., Kharkivska, A. A., Popovych, O. M., Bobyrieva, O. S., \& Kovrei, D. Y. (2020). Reflection of the personality-oriented approach by the subjects of its implementation in Eastern Europe. Revista Tempos e Espaços em Educação, 13(32), 1-20. https://doi.org/10.20952/revtee.v13i32.14967

Zlatea, S., \& Cucui, G. (2016). Motivation and performance in higher education. Procedia -Social and Behavioral Sciences, $180,468-476$.

Received: 31 June 2021 | Accepted: 18 September 2021 | Published: 19 November 2021 